The strategic farmer: A cheese producer with cold feet?

Journal of Business Strategy 2006 27(6) 65-72

\author{
Gerard McElwee University of Lincoln* \\ Alistair Anderson Robert Gordon University \\ Kari Vesala, University of Helsinki
}

*Corresponding author

Lincoln Business School

Brayford Pool

Lincoln, LN6 7TS

England, UK

Telephone $\quad 0044(0) 1522886423$

\title{
E-mail gmcelwee@lincoln.ac.uk
}


The strategic farmer: A cheese producer with cold feet?

\begin{abstract}
Type of article: Research paper

Purpose: The purpose of this article is to explore the strategy of an enterprising farmer. The background problematic is that in Europe, agriculture has faced dramatic pressures for restructuring, and facilitation of the strategic skills of farmers and a stronger entrepreneurial orientation have been suggested as a possible solution for the emerging problems. We use an illustrative case to show how strategy formation and implementation may require different skills, competencies and attitudes.
\end{abstract}

Design, methodology and approach: A case study is used to examine the issues of strategy formation and implementation. Whilst the finding from the case may not be generalisable, our analysis provides an opportunity to conceptually reflect on the issues. These issues may have wider implications beyond the research site.

Findings and implications: The theoretical and case study analyses reveal that the concept of entrepreneurial strategy is ambiguous. Yet, if proper care is taken to distinguish the concept from, and relate it to, the elements in which it is embedded, the notion is a useful tool for both theory and empirical investigation. By applying such a procedure, we show that the contexts of conventional farming and business diversification call for an understanding about the clearly different entrepreneurial skills and appropriate strategies and strategic implementation.

\title{
Practical implications:
}


This research suggests that a major challenge for the agricultural sector is to enable farmers to develop their strategic, marketing and entrepreneurial skills. This requires economic support and greater emphasis on education and training. It is hoped that this research will assist in this challenge.

\section{Key Words-}

Strategic Diversification, Agricultural Marketing, Farming

\section{Entrepreneurship, Entrepreneurial and Strategic Skills}

Gerard McElwee's research interests are in Rural Entrepreneurship and Farmers Entrepreneurial Skills. He is currently working on an EU funded project 'EU-ESoF Framework 6 Developing the entrepreneurial skills of farmers http://www.esofarmers.org/index.html

Professor Alistair R Anderson, BA, MSc, PhD is of Entrepreneurship and Director of the Centre for Entrepreneurship at Aberdeen Business School, Robert Gordon University in Aberdeen, Scotland. He is particularly interested in the social aspects of entrepreneurship. Current themes being explored are rural entrepreneurship, social capital, social constructions and associated topic areas.

Professor Kari Vesala His interested in the social psychology of small business and entrepreneurship. He has worked on a series of studies on small business ownermanagers and is latterly working on social psychological preconditions of entrepreneurship among farmers 


\section{INTRODUCTION}

The focus of this article is the extent to which farmers have the skills to think strategically and entrepreneurially in an increasingly competitive environment. We argue that the issues described here can be also significant issues for other businesses. While some may argue that farmers have lost the ability to be proactive, a less pejorative interpretation may be that farmers have to adapt from being semi-reliant on quasi non-markets to being attentive to market forces. In a sense this is the problem i.e. that farmers are historically embedded in being 'price takers' and that the transition to becoming 'price makers' involves business and economic innovation.

In many ways there are significant barriers to entrepreneurial activity (McElwee and Robson 2005) and these need to be recognised and undestood.

Farmers operate in an arena of extreme and rapid change, clearly evidenced by the shifts from a subsidised environment into a market driven environment suggesting that there is a greater entrepreneurial role for the farmer; in particular the ability to market the product. This article considers these issues by considering a case study of one Finnish Farmer who diversified into Cheese Production and discussing some of the reasons why his diversified business failed to realise its potential. The purpose of this study is to begin to develop an understanding of the business skills of farmers, focussing in particular on marketing strategy skills.

The article is structured as follows. A brief survey of the literature is presented. We describe the Case Study, which is a practical examination of the strategies employed by one farmer, and then present an analysis of the case. 


\section{$\underline{\text { Farmers skills }}$}

Whilst many small business owners perceive themselves as entrepreneurs, running a small business and being an entrepreneur is not the same thing. For Corman and Lussier (1996) the ability to operate an organization requires different skills and abilities than those required for being an entrepreneur. For example, successful longterm operation of a business requires managerial skills, while being an entrepreneur requires innovative skills.

Chen and colleagues (1998) distinguish six different types of entrepreneurial role or tasks: marketing, innovation, management, risk-taking and financial control. Each of these is further divided into sub-categories. For example, innovation includes new venturing and new ideas, new products and services, new markets and geographical territories, new methods of production, marketing and management. In another study which considers the issue of farmers' skills, McElwee (2005) identified six sets of skills.

1. Business and Management Skills: Accountancy, Financial capability, Strategic planning, People Management

2. Cooperation and Networking

3. Information Technology

4. Marketing and Selling

5. Entrepreneurial Qualities and Values

6. Technical and Professional i.e. Farming skills 
Thus entrepreneurship in general, and marketing in particular, seems to involve more than the normal functional and controlling roles of management. Farmers, who may well be adept at managerial functions, the entrepreneurial role may call for new and different skills and attitudes.

It is to this farming context that we now turn. We will present a short narrative of a farmer who started a cheese business. The narrative is based on an extended interview. By interpreting this case, our aim is to consider how issues of entrepreneurial and strategic marketing skills can be understood by farmers. 
The Case Study; "cheesed off with entrepreneurship?"

\section{Context}

Mr. Maitonen, the farmer and his wife, both in their mid 30s, own a farm which was transferred to him from his parents in 1999. They have two young children. Their farm is located in a small village in a municipality in Middle-East Finland and has 40 hectares of cultivated land and 32 milk cows. A new cow house and a building for making cheese were constructed in 1997. After completing a course in cheese production arranged by the University of Helsinki, Mr. Maitonen started making cheese in 1998. He has a college level education in agriculture and has taken additional related courses related to food processing. During his studies he acquainted himself with the legislation about the food industry and prepared plans for establishing a small-scale food-processing firm. He had also considered other diversification activities (e.g., attended a course on berry processing), before finally deciding to move into food processing through cheese production.

Mr. Maitonen employed one person on a two-year apprenticeship contract. He has also bought marketing services from a sales promoter, who has been demonstrating the cheese in Southern Finland. In 2002, he was awarded a commendation for his special cheese products by the National Finnish Association of cheese makers. Since 2000 he has invested a considerable amount of money and time in promoting the product, which had become established locally as a speciality brand. His cheese, mainly sold through local and regional shops, market halls and local tourist venues, is cited it as an example of good quality local produce. Moreover the model of farm diversification was held to be a good example. Nonetheless, despite some initial 
success, the farmer closed the cheese business in the spring of 2004 to concentrate on milk production.

\section{The rise and fall of the cheese business}

Mr. Maitonen describes his cheese business in his own words:

'Back in the early 90's there was a lot of talk going on concerning the additional sources of livelihood in the farming sector. Various kinds of activities were promoted, e.g. machine contracting and timber sawing business were hot topics. I was not at all comfortable with those ideas: primarily since we had dairy cattle, all kinds of machine contracting activities or businesses that had to be performed offfarm would have hindered our activities on-farm too much. I thought that the additional business should rather be connected to our activities on-farm.'

'At that time I was also doing a diploma work in my studies that dealt with the legislation in small-scale food industry. I found out that the legislation was not an obstacle in small-scale food businesses, rather the opposite: it provided a useful framework that seemed to facilitate the starting of such a business. I first applied those ideas in order to facilitate my mother's bakery business, but the ideas also continued to feel personally fascinating. I then took a course on cheese production, where I, for the first time, got to see how the whole process related to cheese production actually works, like how the production unit has to be planned and what it requires. It opened my eyes and an idea about starting a cheese business with a speciality cheese occurred to me. At that time our situation on the farm was such that we had sixteen cows but no chance to expand our milk production, since my father 
who owned the farm belonged to such an age group that he did not get a permission to buy more milk production quota. In such an agricultural-political climate I then started to plan our cheese production unit according to the knowledge gained on the course, and during the next summer we realized those plans.'

However, despite the promising results and recognition, the business was not without troubles. The farmer comments on his experiences in running the cheese business.

'So things were looking quite good, we hired an employee based on a two year's apprenticeship. The special cheese was obviously a good choice for us, we were awarded third prize in special cheese -category in the cheese exhibition arranged by the National Association of cheese makers in 2002. It was a bit surprising since all the nationally biggest producers were also taking part in that category. So we had quite a strong product, we devoted much time, money and effort in order to develop our cheese brand and to facilitate its marketing.'

'In a sense it surprised us how laborious the marketing gets and how much effort it requires. But we nevertheless had confidence in our business and planned to intensify our marketing and improve our packaging concept. We also hired a local sales promoter in order to facilitate the broadening of our market area. This was partly due to the fact that the nearby region of Middle-East Finland does not offer many opportunities to increase our sales, and hence the majority of the trips related to marketing and customer contacts that were located further away in Southern Finland. Such activities require so much time that it would get really difficult for us to manage our dairy cattle at the same time without the aid of hired workforce. Actually we 
worked hard towards these goals until the early spring 2004. But during the spring we lost our sales promoter to a large competitor, or more precisely this large cheese producer started to regard us as a competitor and demanded that the sales promoter quit her cooperation with us. We began to think that if our future really looks like that, that such large companies start to regard us as competitors, that the structure of the trade becomes more centralized and we become more dependent on this production chain, then who are going to survive in such a battle?'

'Another, decisive backlash occurred later this spring, when our employee told us that he intended to quit. His apprenticeship contract ended then, but his quitting was unexpected, although I had had some forebodings during the latest weeks. At that time the planting season kept us busy, and it was simply impossible for us to imagine that we could manage to find and train a new employee. I critically evaluated the situation and thought that we should have progressed exactly in the opposite direction: we should have grown as an enterprise and started to build contacts with new actors and production chains. So the things would have become more laborious even if our employee would have continued with us. In this situation we simply did not have the capability. So I decided to give up the cheese business in spring 2004 and to concentrate on milk production. I believe that this is was quite a good choice for us; I have been clearing few hectares of additional land for cultivating and I would be willing to buy or rent more land, but unfortunately there is not much land available in the village. We have a quota for both selling the milk to dairy and for direct sale, and this combination may provide some potential opportunities for us. We sort of get rid of all the unessential activities and concentrated on our core business. Since I really think that also the actors operating in conventional farming 
should be regarded as entrepreneurs, and even more importantly: they should run their enterprise as entrepreneurs do.'

\section{Analysis}

In this section we shall consider our farmer's explanation, as provided in his narrative, of his decision to close his cheese business. Our argument is that whilst Mr. Maitonen's explanations are both logical and correct they do seem point to a much larger underlying issue; a problem about lack of "marketing and entrepreneurial" skills and perhaps an issue about the farmer's attitude to marketing.

He provided several justifications for quitting the cheese business. These seem to fall into three broad themes:

Practical - The employee resigned when his apprenticeship contract ended. This announcement was a surprise to Mr Maitonen and his wife, whilst the cheese business demanded increasingly more of the farmer's time in marketing. They both knew that it would have taken a long time to train a new employee.

The increasing demands of marketing- Marketing of the cheese was becoming more and more important, because the business was increasing all the time. The sales promoter renewed her contract with another client, a larger food processing company, and this client demanded that the sales promoter quit working for the farmer (whom this client now considered as a competitor).

Need to expand the marketing effort- Local markets were not large enough for profitable business, but the logistics and marketing required for the expansion of the 
market area would have taken more money, time and effort. Some attempt to utilise a typical food chain marketing channel would have been necessary, but the benefits of a niche product would have been lost. The competition would have become harder if they had followed the "natural" growth curve of the enterprise and the cheese industry.

Maitonen seems to be declaring that despite the success of the cheese business, the efforts required to maintain the marketing momentum would be too great. Moreover, Maitonen suggested that farmers ought to have a clear insight concerning the business idea and the demand in the market place and that the business needs to be profitable and gain enough volume. It is not enough to have an innovative product. In addition, marketing and selling demand certain skills and lots of time and effort which should be taken into account when planning business diversification. He also pointed out that the management of dairy cattle is difficult to combine with the demands of marketing and active customer orientation, unless there are different people to take care of each activity.

In consequence it appears to us that our farmer clearly recognised the importance of marketing in his entrepreneurial venture, that he was aware of the need for skilled marketing for entrepreneurial success, but he was not prepared to make that effort himself. So when difficulties arose, difficulties which required additional marketing effort, he chose to close the business. This suggests to us, because of his obvious understanding of marketing, that the underlying issue was one of attitude, rather than merely skill. 
In the narrative, Maitonen commented upon the different nature of the activities related to diversified farming (i.e., the cheese business) and conventional farming (i.e., the dairy cattle farming). In many respects the entrepreneurial tasks associated with conventional farming appear different than those associated with diversified business. For example, product development and marketing related functional tasks are mentioned only in the case of the cheese business. In addition, the skills of identifying business opportunities and finding the resources that are needed in pursuing these opportunities are solely connected to the diversified business. Thus our farmer makes a clear distinction between the categories of skills.

According to some studies (Carter, 2001; Vesala \& Peura, 2003) conventional farmers are not as entrepreneurial as non-farm business owners, or farmers involved in business diversification. On the other hand, Salamon (1992) has emphasised that it is possible to identify entrepreneurial behaviour among conventional farmers Nonetheless, at least according to our narrative, the entrepreneurial tasks are considered to be somewhat different in conventional farming than in a diversified business. This does lend some support for our argument that different kinds of entrepreneurial skills and attitudes are needed in conventional farming compared to diversified business. .

The lack and avoidance of these skills, attributes and attitude is somewhat surprising in the case of our farmer. In his mid-30's, the farmer is a father of two young children and owner of the family farm. He had a college level education in agriculture and additional education related to the manufacturing of cheese. He was thus well educated and informed. Moreover we note his self confidence; he had a strong faith in his product and believed from the start that his unit would produce a quality cheese. 
Yet when we consider his account, he attributes his quitting of the cheese business to situational factors. According to his narrative, the obstacles encountered by the cheese business became insurmountable and hence he thought that he made a wise move by focussing solely on conventional farming. He faced hardening competition, loss of important social resources and so on. As he expanded he began to face the powerful forces of vertical integration in food chains. Such an account does not imply that the farmer lacked any critical entrepreneurial skills. Indeed, this is very much the tone of the farmer's own words when he is making sense of the events: he presents himself as a skilful entrepreneur. He identified a potential niche product, which gained some initial success at least in the local markets and learned the skills and techniques of cheese production and product development well and he encountered no serious obstacles. He was able to assess the expected workload and to hire the required labour force. During the interview he demonstrates that he is able to carefully analyse the needs of business growth and the demand related to different markets. Thus from the perspective of business knowledge he appears to be well informed and indeed, did everything that a "good" entrepreneur should do!

The quitting of the cheese business may be viewed as a failure and that Maitonen's accounts are not credible. Perhaps the cause can be attributed, after all, to himself. As the owner of the organisation, the responsibility was his, thus indicating some shortcomings in his entrepreneurial skills. We could, for example, question the extent of his skills; he was not able to make the employee stay and he was not prepared to respond positively to the loss of his sales promoter. We thus have some reasons to argue that the decline of the cheese business could be attributed to the lack of particular entrepreneurial skills of the farmer 
There is another interpretation which draws on individual factors, which cannot be considered as entrepreneurial skills. We may propose that there were some decisive personal factors that might as well account for the farmer's choice to give up the cheese business and to return to conventional farming. Personal involvement in the management of the family farm was important to him and at the same time the family duties kept him attached to the farm. Similarly, his education was focused on activities performed on-farm and he felt that his efforts in the production activities onfarm were decisive for both the cheese business and the dairy business. Taken together, one could argue that on the level of personal attitudes, he strongly preferred the elements associated with conventional farming; his whole life-style conformed to the farming environment rather than to the demands of the business environment. As he stated himself, the continuation of the cheese business would have demanded more of his own time in activities outside the farm, such as sales promotion.

To set the specifics of this study in a more general context it is useful to look at the general situation about marketing skills for farmers. McElwee (2005) had asked 18 respondents involved in the Farm Supply chain, "What are the most important skills that a farmer needs in order to succeed in the farming industry?" The respondents identified a great number of skills, but the most significant skill set identified strategic awareness. Consequently, it appears that within the industry, informed players are aware of the issue of attitudes and how the role they contribute to business success.

\section{Conclusions}


In broad terms, we can safely conclude that marketing is critical for new entrepreneurial farm ventures. This is evidenced by the comments from the stakeholders in McElwee's (2005) study. For the cheese making business, the role of marketing was vital and was recognised as such by our farmer. However, it also appears that Mr Maitonen simply did not want to change his attitudes. He was not prepared to shift his activities from the operation and management of his dairy farm to develop new strategies for marketing his prize winning cheese.

Mr. Maitonen had decided to diversify from his dairy farm and set up a cheese making business but after some initial success he closed his cheese making to concentrate on dairy farming. Our analysis of the case provides explanations of the reasons that led him to choose conventional farming instead of business diversification. The first one focuses on situational and contextual factors, the second on the lack of entrepreneurial skills, and the third on the personal characteristics and attitudes of the farmer. The analysis thus supports the idea that in, at least, the context of farming, entrepreneurial skills should be distinguished from managerial skills. Importantly, it gives us strong reasons to argue that credible explanations concerning the performance of the farm enterprise cannot be straightforwardly reduced to the presence or absence of entrepreneurial skills.

In addition to the "conventional" entrepreneurial skills we can also attribute the farmer's entrepreneurial behaviour to situational and personal factors. Secondly, the case highlights the problematic and context dependent nature of the entrepreneurial skills themselves; it demonstrates that the entrepreneurial skills required for diversified farming are clearly different from the ones required in conventional 
farming. Nevertheless, a closer look at the farmer's behaviour and challenges encountered in the contexts of conventional and diversified farming suggests that it was precisely in the context of the diversified cheese business, where the lack of certain crucial entrepreneurial skills - related to the ability to acquire the resources that are needed in the pursuit of business opportunities, i.e. marketing his business through for example, social networking - posed insurmountable problems for the running of the enterprise.

The farmer obviously had learned many skills required in managing the basic functional tasks in both diversified business and conventional farming: he had the technical skills required in cheese making and dairy cattle farming, he had the ability to plan, organize and execute the plan as well as the skills to manage and control the enterprise financially. He also had some success in managing certain meta-level tasks, identifying business opportunities, growing the business, and innovative product development. However, in the context of diversified cheese business the farmer did not have the skills, or attitude necessary in managing certain critical metalevel tasks. These include pursuing opportunities regardless of current resources, and social networking to compensate for the changes in the customer and employee relationships. These tasks were closely related to the market orientation required in the context of diversified business but relatively irrelevant in the context of conventional farming.

The notion that different skills are required in different business contexts leads us to a second theoretical distinction. This distinction concerns the relationship between skills, social context, and attitudes. It can be used to further elaborate the role of 
entrepreneurial skills in the case of farmers. By looking at the situational factors and the attitudes towards these factors, we recognized clear differences between business contexts: the context of diversified cheese business was characterized by the abundance of factors related to dealing with other agents, such as customers, competitors, and employees. On the other hand, the pressures of social constraints, the vertical integration of the food chain and the overpowering competitors made a difference to Maitonen.

By including these dimensions of situational and personal factors in the analysis we are able to see the whole configuration of relationships in which the entrepreneurial skills have to be embedded. This analytical configuration of both context and skills makes Maitonen's return to conventional farming much more understandable: it suited his entrepreneurial skills, personal attitudes that had provided him a sense of self-efficacy.

Studies in the area might benefit from the use of analytical frameworks that aim to map the characteristics of the farmer and the farm business with the existing and required entrepreneurial skills (see e.g. McElwee, 2004.) By following this strategy we might be better able to discern the various alternatives in developing the entrepreneurial skills in the context of farming, and also to understand the choices, which the farmer needs to make. 
What is clear is that all stakeholders interviewed by McElwee (2005) recognise that farmers need to develop their strategic and entrepreneurial capacity if they want to continue in business. This research suggests that a major challenge for the agricultural sector is to enable farmers to develop their strategic skills- not only diversified activities, but indeed core businesses. Moreover this will only be achieved if farmers are prepared to change their attitudes too!

\section{References}

Anderson, A., and McKain, R. (2005) 'Rural Entrepreneurship: perspectives of values in the rural environment' Journal of Rural Research and Policy Vol. 12 N0 4 pp 7183

Anderson, A.R. and Jack, S.L. (2000), "Teaching the Entrepreneurial Art" in Evans, D.S. (ed.), International Dimensions of Teaching Entrepreneurship, Cole Superieur, Poitiers, pp. 84-105.

Beedell, J., and Rehman, T. (2000) 'Using social-psychology models to understand farmers' conservation behaviour', Journal of Rural Studies, Vol. 16, Issue 1, pp. 117127.

Carter, S. (2001), "Multiple business ownership in the farm sector: Differentiating monoactive, diversified and portfolio enterprises", International Journal of Entrepreneurial Behaviour \& Research, vol. 7, no. 2, pp. 43-59.

Chen, C.C., Greene, P.G. and Crick, A. (1998), "Does Entrepreneurial Self-Efficacy Distinguish Entrepreneurs from Managers?", Journal of Business Venturing, vol. 13, no. 4 , pp. 295-316. 
Corman, J., and Lussier, R.N. (1996) Small Business Management, a planning approach, Irwin/McGraw-Hill, United States of America.

Jack, S.L. and Anderson, A.R. (1999), "Entrepreneurship Education within the Enterprise Culture. Producing Reflective Practitioners", International Journal of Entrepreneurship Behaviour \& Research, vol. 5 no. 3, pp. 110-125.

Johannison, B. (1992), "In Search of a Methodology for Entrepreneurship research", unpublished draft circulated at RENT VII, November.

McElwee, G., and Robson, A (2005) Diversifying the farm: opportunities and barriers Finnish Journal of Rural Research and Policy 4/2005 84-96

Salamon, S. (1992), Prairie Patrimony: Family, Farming, and Community in the Midwest, The University of North Carolina Press, Chapel Hill, NC.

Vesala, K.M. and Peura, J. (2003), "Farmers with Additional Business, Mono-Active Farmers and Non-Farm Rural Small Business Owners in Comparison from the Viewpoint of Entrepreneurial Role Expectations", in Borch, O.J. and Ronning, L. (eds.), Entrepreneurship in Regional Food Production, Nordlandsforskning: NFRapport nr. 26/2003, Bodö, pp. 56-82. 